\title{
An Anti-CD9 Monoclonal Antibody Promotes Adhesion and Induces Proliferation of Schwann Cells in vitro
}

\author{
Michael Hadjiargyrou and Paul H. Patterson \\ Division of Biology, 216-76, California Institute of Technology, Pasadena, California 91125
}

\begin{abstract}
We have recently found that CD9, a cell surface glycoprotein involved in intercellular signaling in hematopoietic cells, is also expressed by neurons and glia in the peripheral nervous system. Antibody perturbation experiments were conducted to examine the function of CD9 in neural cells. Three antiCD9 monoclonal antibodies (mAbs) (ROCA1, ROCA2, B2C11) were tested for their ability to promote adhesion of several Schwann cell lines (S-16, RN22, JS1), primary Schwann cells and PC12 cells. Only B2C11 promotes adhesion in all cells tested. Although ROCA2 immunolabels living cells strongly, it had no effect on the adhesion of any of these cells. In addition, ROCA1 and several positive-staining, control mAbs also had no effect. Another mAb, 192-IgG, directed against the low affinity NGF receptor, also promotes the adhesion of S-16, PC12, and primary Schwann cells. In addition to adhesion, contact of S-16 Schwann cells with B2C11 specifically induces morphological changes and robust proliferation. None of the other mAbs, including 192-IgG, induce proliferation of S-16 cells. These results provide evidence that CD9 may be involved in signaling, activation and growth regulation of cells in the nervous system.
\end{abstract}

[Key words: CD9, Schwann cells, adhesion, proliferation, monoclonal antibody]

CD9 is a 24-27 kDa cell surface glycoprotein expressed at high levels on the surfaces of developing B-lymphocytes, platelets, eosinophils, basophils, stimulated T-lymphocytes and certain neuroblastoma cell lines (Kersey et al., 1981; Jones et al., 1982; Kemshead et al., 1982; Komada et al., 1983; Boucheix et al., 1987; Boucheix and Benoit, 1988; Von dem Borne et al., 1989). This protein is a member of the "tetraspan" family of four transmembrane domain-containing proteins that are thought to be involved in the regulation of cell growth (Gil et al., 1992). Other members of this family are described in an accompanying article (Kaprielian et al., 1994). CD9 was purified from human platelets (Higashihara et al., 1990; Boucheix et al., 1991; Lanza et al., 1991) and its cDNA cloned (Boucheix et al., 1991; Lanza et al., 1991). Other CD9 homologs were cloned from bovine

\footnotetext{
Received Mar. 29, 1994; revised June 13, 1994; accepted July 12, 1994.

We thank Dr. Richard Quarles for the S-16 cells, Dr. David Anderson for the RN22, JS1, and PC12 cells; Doreen McDowell for media preparation; and Drs. Joshua Sanes, Zaven Kaprielian, Karen Allendoerfer; and Kyung-Ok Cho for their constructive comments on the manuscript. This work was supported by an NINDS grant to P.H.P. and an American Heart Association Research Fellowship and an NIH Training Grant fellowship to M.H.

Correspondence should be addressed to Dr. Michael Hadjiargyrou, Division of Biology, 216-76, California Institute of Technology, Pasadena, CA 91125.

Copyright (C) 1995 Society for Neuroscience $0270-6474 / 95 / 150574-10 \$ 05.00 / 0$
}

ocular ciliary epithelial cells (Martin-Alonson et al., 1992), monkey kidney (Vero) cells (Mitamura et al., 1992), and from a mouse kidney cDNA library (Rubinstein et al., 1993). In a search for cell membrane molecules expressed in rostrocaudal gradients the PNS, our group identified three mAbs (ROCA1, ROCA2, $\mathrm{B} 2 \mathrm{C} 11$ ) that bind on the surfaces of peripheral glia and neurons (Suzue et al., 1990; Kapriclian and Patterson, 1993; Tole and Patterson, 1993). We have now identified and cloned the antigen for these $\mathrm{mAbs}$ as CD9 from rat sciatic nerve (Kaprielian et al., 1994).

Perturbation studies using anti-CD9 $\mathrm{mAbs}$ and transfections have been useful in examining the function of $\mathrm{CD} 9$ in hematopoietic cells. Anti-CD9 mAbs stimulate fibrin clot retraction by fibroblasts (Azzarone et al., 1985), induce homotypic adhesion in pre-B lymphocytes (Masellis-Smith et al., 1990), inhibit the motility of lung adenocarcinoma cells (Miyake et al., 1991 ), augment the adherence of neutrophils to endothelial cells (Forsyth, 1991), and elicit phosphatidylinositol turnover, phosphatidylinositol biosynthesis, and protein-tyrosine phosphorylation in human platelets (Yatomi et al., 1993). Transfection of CD9 elevates diphtheria toxin receptors on toxin-sensitive cells (Mitamura et al., 1992), induces hypersensitivity of mouse cells to diphtheria toxin (Brown at al., 1993), and suppresses cell motility in several cell lines (Ikeyama et al., 1993).

Extensive work with human platelets showed that anti-CD9 mAbs induce activation and aggregation, leading to what is termed an adherent phenotype (Jennings et al., 1990; Griffith et al., 1991). Rather than being directly involved in adhesion, it is thought that CD9, together with other proteins, may function in the initiation of signals leading to cell adhesion. For example, an association between CD9 and the integrin GPIIbIIIa is induced during platelet activation (Slupsky et al., 1989). The finding that platelets from patients with Glanzman's thrombasthenia, which lack this integrin but not $C D 9$, are not activated by anti-CD9 $\mathrm{mAbs}$ further indicates that this CD9-GPIIbIIIa complex is involved in platelet aggregation (Bouchiex et al., 1983; Higashihara et al., 1985; Miller et al., 1986).

Given our localization of CD9 to peripheral neurons and glia (Tole and Patterson 1993; Kaprielian et al., 1994), we asked whether CD9 can mediate adhesion and cell growth in neural cells. We report here that one anti-CD9 $\mathrm{mAb}, \mathrm{B} 2 \mathrm{C} 11$, promotes adhesion of a number of Schwann cell lines, PC12 cells and primary rat Schwann cells. In addition, this $\mathrm{mAb}$ also stimulates proliferation of one of the Schwann cell lines. An accompanying article further demonstrates that another anti-CD9 $\mathrm{mAb}$ enhances motility and migration in primary Schwann cells (Anton et al., 1994). 


\section{ROCA1 ROCA2 B2C11 192-IgG}

Figure 1. Immunodetection of CD9 and p75 expression in S-16 Schwann cell extracts after immunoblotting of $1 \%$ NP-40 supernatant and pellet $(S / P)$ fractions. ROCA1, ROCA2, and $\mathrm{B} 2 \mathrm{C} 11$ specifically recognize the $26 \mathrm{kDa} C D 9$ band, while the control mAb 192-IgG specifically labels the $75 \mathrm{kDa}$ low affinity NGF receptor. Primary antibody binding was visualized with a peroxidase-conjugated goat anti-mouse IgG secondary antibody. Approximately 100 $\mu \mathrm{g}$ of protein was loaded in each lane.

\section{Materials and Methods}

Antibodies. Monoclonal Abs to rat surface proteins, CD9 (ROCA1, ROCA2 and B2C11), p75 LNGFR (192-IgG), Thy-1 (OX-7), NGF-inducible large external (NILE) glycoprotein (ASCS4), and a heparan sulfate proteoglycan (pg22) have been previously described (Mason and Williams, 1980; Sweadner, 1983; Akeson and Warren, 1984; Chandler et al., 1984; Matthew et al., 1985; Suzue et al., 1990; Kaprielian and Patterson, 1993; Kaprielian et al., 1994). All of these mouse IgG mAbs were purified from hybridoma supernatants using the $\mathrm{mAb}$ Trap-G kit (Pharmacia), and stored at $-80^{\circ} \mathrm{C}$ in a solution containing $1 \mathrm{M}$ glycine$\mathrm{HCl}(\mathrm{pH} 2.7)$ and $60 \mathrm{~mm}$ Tris- $\mathrm{HCl}(\mathrm{pH}$ 9) (final pH 7.6).

Cell culture. The rat Schwann cell line, S-16 (Goda et al., 1991), and the rat Schwannomas, RN-22 (Pfeiffer et al., 1978) and JS1 (Kimura et al., 1990), were grown in Dulbecco's modified Eagle's medium (DMEM) supplemented with $10 \%$ fetal bovine serum (FBS, Hyclone), glucose $(7.5 \%)$, L-glutamine (50 mM) and penicillin-streptomycin $(50 \mathrm{U} / \mathrm{ml}$ and $50 \mu \mathrm{g} / \mathrm{ml}$, respectively) (GIBCO BRL). The rat pheochromocytoma cell line, PC12 (Greene and Tischler, 1976), was grown on collagen-coated tissue culture plates $(10 \mathrm{~cm}$, Falcon) in RPMI 1640 medium supplemented with $10 \%$ heat-inactivated horse serum, $5 \%$ FBS, as well as glucose, glutamine, and penicillin-streptomycin, as above. All cell lines were maintained at $37^{\circ} \mathrm{C}$ in a $5 \% \mathrm{CO}_{2}$, humidified incubator.

Primary Schwann cells were isolated by collagenase digestion of neonatal rat sciatic nerve. Nerves were dissected and desheathed from 12 rats and then placed in L-15 air medium (Hawrot and Patterson, 1979) on ice. Nerves were cut into $2 \mathrm{~mm}$ pieces, washed in cold $\mathrm{Ca}^{2+} / \mathrm{Mg}^{2+}-$ free Hanks' solution, and suspended in $2 \mathrm{ml}$ of collagenase $(1 \mathrm{mg} / \mathrm{ml}$, Worthington; in $\mathrm{Ca}^{2+} / \mathrm{Mg}^{2+}$-free Hanks) that had previously been adjusted to $\mathrm{pH} 7$ with dilute $\mathrm{NaOH}$. Incubation was at $37^{\circ} \mathrm{C}$ for $60 \mathrm{~min}$, with gentle trituration every 20 min using a fire-polished Pasteur pipette. Cells were washed $2 \times$ with L-15 air containing $10 \%$ FBS. Undigested tissue was removed by a Falcon cell strainer. The yield was approximately $4 \times 10^{5}$ Schwann cells/rat. After a final wash in serum-free medium the cells were treated identically to the $\mathrm{S}-16$ cells for use in the adhesion assay.

Cell adhesion assay. Cells were tested for adhesion to mAbs bound to nitrocellulose in an assay modified from that of (Lotz et al., 1989). Each well of a 96 well plate (Falcon) was coated with 5 liters of a solution of $5 \mathrm{~cm}^{2}$ nitrocellulose (Schleicher \& Schuell, type BA85) dissolved in $6 \mathrm{ml}$ of methanol (Lagenaur and Lemmon, 1987), and allowed to dry for $15 \mathrm{~min}$ in a tissue culture hood. Each purified $\mathrm{mAb}$ was dissolved at various concentrations in $50 \mu \mathrm{l}$ of $100 \mathrm{~mm}$ carbonate buffer ( $\mathrm{pH} \mathrm{9.6),}$ and added to the wells. The mAbs were allowed to bind to the nitrocellulose for 1-2 $\mathrm{hr}$ at RT followed by two washes with $1 \times$ phosphatebuffered saline (PBS). To prevent nonspecific cell binding, the wells were then blocked for $1 \mathrm{hr}$ at $37^{\circ} \mathrm{C}$ with a $5 \%$ BSA solution (in PBS), and afterwards washed $1 \times$ with PBS. For the assay, cells were removed from dishes by gently rolling glass beads over the dish, washed in serum-free medium, and resuspended in serum-free medium (DMEM, supple- mented with glucose, L-glutamine and penicillin/streptomycin). To generate a single cell suspension, the cells were passed through a cell strainer (Falcon 2350), counted, and added to the test wells at a density of 5$10 \times 10^{3}$ cells/well in a volume of $100 \mu \mathrm{l}$. The plates were incubated at $37^{\circ} \mathrm{C}$ for $1-2 \mathrm{hr}$. At the end of the incubation, each test well was filled with serum-free DMEM and the entire plate was gently covered with an adhesive pressure sensitive film (Falcon 3073). The covered plate was then centrifuged upside-down at $500 \mathrm{rpm}$ for $5 \mathrm{~min}$ in a Beckman $\mathrm{J}-6 \mathrm{~B}$ centrifuge (with braking) to remove the unbound cells. The adhesive film and most of the excess medium were then removed gently with a multiwell pipetman, leaving behind the adhered cells in $100 \mu 1$ of DMEM. Adherent cells were assayed by the MTS/PMS assay (Barltrop et al., 1991). Twenty microliters of a solution containing the tetrazolium compound [3-(4,5-dimethylthiazol-2-yl)-5-(3-carboxymethoxyphenyl)-2-(4-sulfophenyl)-2H-tetrazolium, MTS] and an electron coupling reagent (phenazine methosulfate, PMS) (CellTiter $96 \mathrm{AQ}_{\text {ucous }}$ Promega) were added to each well, followed by an incubation of $2-4 \mathrm{hr}$ at $37^{\circ} \mathrm{C}$. The optical density at $492 \mathrm{~nm}$ was determined with an 96 well plate reader. These data are expressed as the mean O.D. \pm SD of triplicate determinations after subtraction of background (no cells added).

Cell proliferation assay. Cell proliferation experiments were conducted in plates identical to those used for adhesion measurements. Once the unbound cells were removed, the plates were further incubated in serum-free medium for 24,48 , or $72 \mathrm{hr}$. Cell number was then determined using the MTS/PMS solution as described above.

For the micrographs showing cell proliferation in Figure 9, S-16 cells were plated on spots of $\mathrm{B} 2 \mathrm{C} 11$ and 192-IgG on $3.5 \mathrm{~cm}$ petri dishes (Falcon). These dishes were first coated with the nitrocellulose/methanol solution and air dried for $15 \mathrm{~min}$ at RT. In each dish, $250 \mathrm{ng}$ (in $1 \mu \mathrm{l}$ of PBS) of $\mathrm{mAb}$ were dotted in the center and allowed to adsorb for 1$2 \mathrm{hr}$ at RT. The dishes were then washed $2 \times$ with PBS and blocked with $5 \% \mathrm{BSA}$ in PBS for $1 \mathrm{hr}$ at $37^{\circ} \mathrm{C}$. Following a wash with PBS, a single-cell suspension of S-16 cells in serum-free DMEM was plated at a density of $1.25 \times 10^{5}$ cells/dish for the B2C11-containing dish and $2.5 \times 10^{5}$ for the 192 -IgG-containing dish. Cells were allowed to adhere for $1.5 \mathrm{hr}$ at $37^{\circ} \mathrm{C}$, and unbound cells were removed with two washes of serum-free-DMEM. The same fields were photographed at 2, 24, and $72 \mathrm{hr}$.

Quantitation of immobilized $m A b$. To determine how well each $\mathrm{mAb}$ used in the perturbation studies adheres to the culture plate, wells were coated with each $\mathrm{Ab}$ and the amount of protein was assayed. Duplicate wells of a 96 well plate were coated with $5 \mu$ l of a nitrocellulose/methanol solution and allowed to dry for $15 \mathrm{~min}$ at RT. Various amounts of each $\mathrm{mAb}$ diluted in $50 \mu \mathrm{l}$ of $100 \mathrm{~mm}$ carbonate buffer were added in each well and allowed to adhere for $1-2 \mathrm{hr}$ at RT. The wells were washed $2 \times$ with PBS to remove the unbound Ab, followed by the addition of $150 \mu \mathrm{l}$ of PBS and $150 \mu \mathrm{l}$ of a $60^{\circ} \mathrm{C}$ preheated solution of $50: 1$ Reagent $\mathrm{A}$ and $\mathrm{B}$ (BCA protein assay, Pierce). The plate was then incubated at $60^{\circ} \mathrm{C}$ for $1 \mathrm{hr}$ followed by a $15 \mathrm{~min}$ cooling period at RT. The optical 


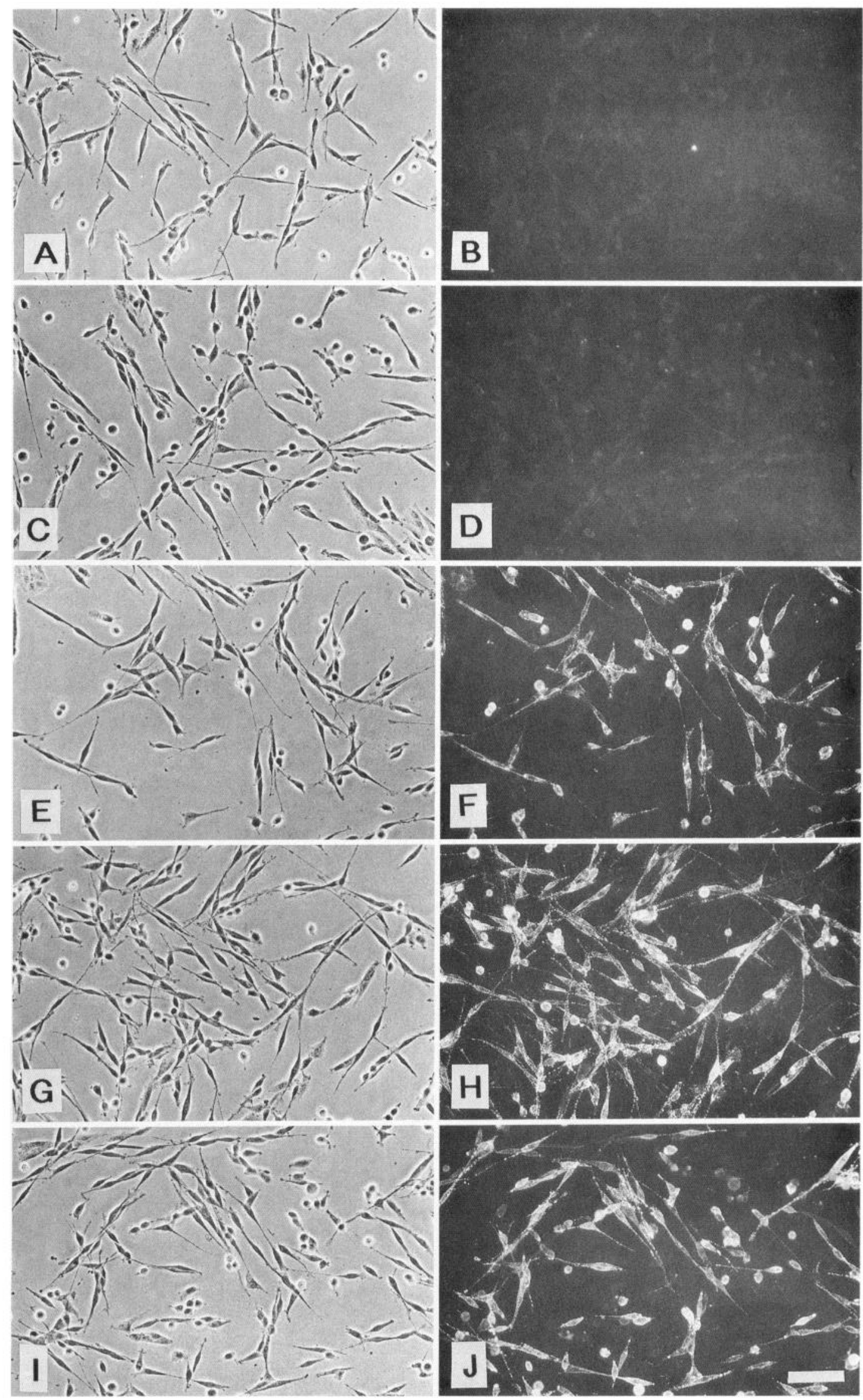


density at $570 \mathrm{~nm}$ was determined with a 96 well plate reader. The amount of each immobilized $\mathrm{Ab}$ was determined by comparing the O.D. obtained with those from wells containing known amounts of $\mathrm{mAb}$. When $0.5 \mu \mathrm{g}, 1 \mu \mathrm{g}, 2.5 \mu \mathrm{g}$, and $5 \mu \mathrm{g}$ was used, $40 \%, 28 \%, 16 \%$, and $13 \%$, respectively, was found to adhere on the nitrocellulose/methanol substrate. Very similar results were obtained for all of the mAbs used herc.

Immunocytochemistry. S-16 cells were plated on sterile glass coverslips inside a six-well dish (Falcon \#3046) and grown for 2-3 d. The cells were then stained for surface antigens with purified mAbs $(20 \mu \mathrm{g} /$ $\mathrm{ml}$ ) for 45-60 min at RT. Cells were then washed with culture medium and incubated for $30-45 \mathrm{~min}$ at RT with fluorescein isothiocyanate (FITC) conjugated goat anti-mouse IgG secondary antibody (Hi-F, Antibodies Inc.) diluted 1:200 in serum-containing culture medium. Cells were then washed $2 \times$ with culture medium and fixed with $3 \%$ formaldehyde (diluted in serum-containing culture medium) for 10-15 min at RT. Cell-containing coverslips were washed with culture medium and mounted on glass slides in glycerol, containing $8 \mathrm{mg} / \mathrm{ml} \mathrm{n}$-propyl gallate (dissolved in $100 \mathrm{~mm}$ Tris- $\mathrm{HCl}, \mathrm{pH}$ 9). Cells were viewed and photographed using an inverted Nikon fluorescence microscope (Diaphot 300).

Protein preparation and immunoblotting. Membrane and cytoskeletal fractions were prepared by homogenization and differential centrifugation, as described previously (Kaprielian and Patterson, 1993). Detergent-soluble and -insoluble fractions were prepared with 1\% NP-40 as described previously (Kaprielian and Patterson, 1993), as were SDSPAGE and immunoblotting procedures.

\section{Results}

\section{Expression of CD9 in S-16 Schwann cells}

To determine whether CD9 is expressed in S-16 cells, the antiCD9 mAbs ROCA1, ROCA2, and B2C11 were used for immunoblotting and immunocytochemistry. All three anti-CD9 $\mathrm{mAbs}$ detected the $26 \mathrm{kDa}$ CD9 band in detergent-soluble (supernatant) but not insoluble (pellet) membrane fractions (Fig. 1). A second, minor band at $28 \mathrm{kDa}$, recognized only by ROCA 2 and $\mathrm{B} 2 \mathrm{C} 11$, represents a glycosylated form of CD9 (Kaprielian and Patterson, 1993). These mAbs do not bind significantly to any other proteins on immunoblots of either detergent-insoluble or soluble fractions. These results are consistent with those obtained previously using ROCA 1 and ROCA 2 to identify CD9 in membrane extracts of adult sciatic nerve (Kaprielian and Patterson, 1993). As expected, the mAb 192-IgG detected the low affinity NGF receptor, p75, exclusively in the supernatant fraction (Fig. 1).

Expression of CD9 on the cell surface was detected by immunostaining living S-16 cells using the three anti-CD9 mAbs. Strong binding of ROCA2 and B2C11 on the cell bodies and processes of bipolar Schwann cells is illustrated in Figure 2. In contrast, ROCA1 does not detectably bind the surfaces of these cells. In addition, mAb 192-IgG strongly labels the surface of S-16 cells (Fig. 2).

\section{Immobilized antibodies promote adhesion of $S-16$ cells}

Given that anti-CD $9 \mathrm{mAbs}$ can induce an adherent phenotype in a variety of hematopoietic cells, it was logical to ask whether the same is true of Schwann cells, which express significant levels of CD9 in vivo and in vitro. In the first experiments, we tested the ability of various mAbs to enhance $S-16$ cell adhesion to collagen or fibronectin substrata when the mAbs were added in

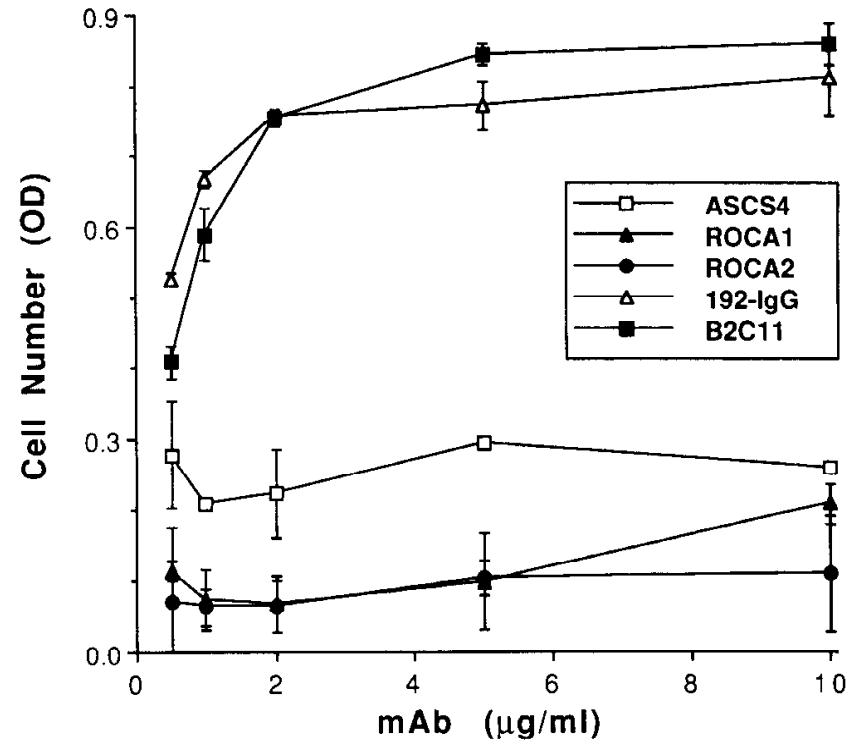

Figure 3. Adhesion of S-16 cells to immobilized mAbs; $1 \times 10^{4}$ cells were added to each well of a 96 well plate containing various concentrations of each $\mathrm{mAb}$ that were immobilized on a nitrocellulose substratum. Cells were then exposed to the immobilized mAbs in serum-free medium for 90 min prior to removal of unbound cells by centrifugation. The number of adherent cells was determined spectrophotometrically by the MTS/PMS assay. The entire assay is described in detail in materials and methods. Not shown in graph were the value of cells that adhered on $5 \%$ BSA (used as a negative control) which was $0.168 \pm$ 0.033 .

solution, with and without sccondary, goat anti-mouse antibodies. We were unable to demonstrate an effect of the three anti-CD9 mAbs (ROCA1, ROCA2, and B2C11), or two control mAbs, 192-IgG (which labels the surface of $S-16$ cells, and thus serves as a positive control) and ASCS4 (anti-NILE), (which does not stain these cells, negative control) (data not shown). In a second set of experiments, adhesion assays were conducted with the same mAbs attached to latex beads and covaspheres. $\mathrm{S}-16$ cells were incubated with $\mathrm{mAb}$-coated beads or covaspheres in solution for $1 \mathrm{hr}$ at RT, and then plated on either immobilized fibronectin or tissue culture plastic surfaces. None of the mAb-coated beads or covaspheres influences the rate of $\mathrm{S}-16$ cell binding to these surfaces (data not shown).

In contrast, when these mAbs were tested by immobilizing them on a nitrocellulose-coated dish surface, a striking enhancement of S-16 cell adhesion is observed on two mAbs. As can be seen in Figure 3, B2C11 and 192-IgG both promote adhesion after $90 \mathrm{~min}$ of exposure at input $\mathrm{mAb}$ concentrations ranging from $0.5-10 \mu \mathrm{g} / \mathrm{ml}$. Surprisingly, ROCA2 has no effect on cell adhesion, despite its strong immunostaining of the cell surface. The lack of effect of ROCA 2 shows that not all immobilized mAbs can influence cell adhesion, and indicates that simple Abantigen binding is not sufficient for adhesion at $500 \mathrm{rpm}$. The ROCA1 and ASCS4 mAbs, which do not label these cells, also have no effect on cell adhesion. The cells that bind to immo-

Figure 2. Surface immunofluorescence labeling of CD9 and $\mathrm{p} 75 \mathrm{in} \mathrm{S}-16$ cclls. Living cells were incubated with purified $\mathrm{mAb}(20 \mu \mathrm{g} / \mathrm{ml})$ and secondary FITC-conjugated, goat anti-mouse IgG secondary $\mathrm{Ab}$, and then fixed as described in Materials and Methods. $A$ and $B$, Phase and fluorescent views of cells stained with secondary mAb. $C$ and $D$, Phase and fluorescent views of cells stained with ROCAl. $E$ and $F$, Phase and fluorescent views of cells stained with ROCA2. $G$ and $H$, Phase and fluorescent views of cells stained with B2C11. $I$ and $J$, Phase and fluorescent views of cells stained with 192-IgG. Scale bar, $100 \mu \mathrm{m}$. 


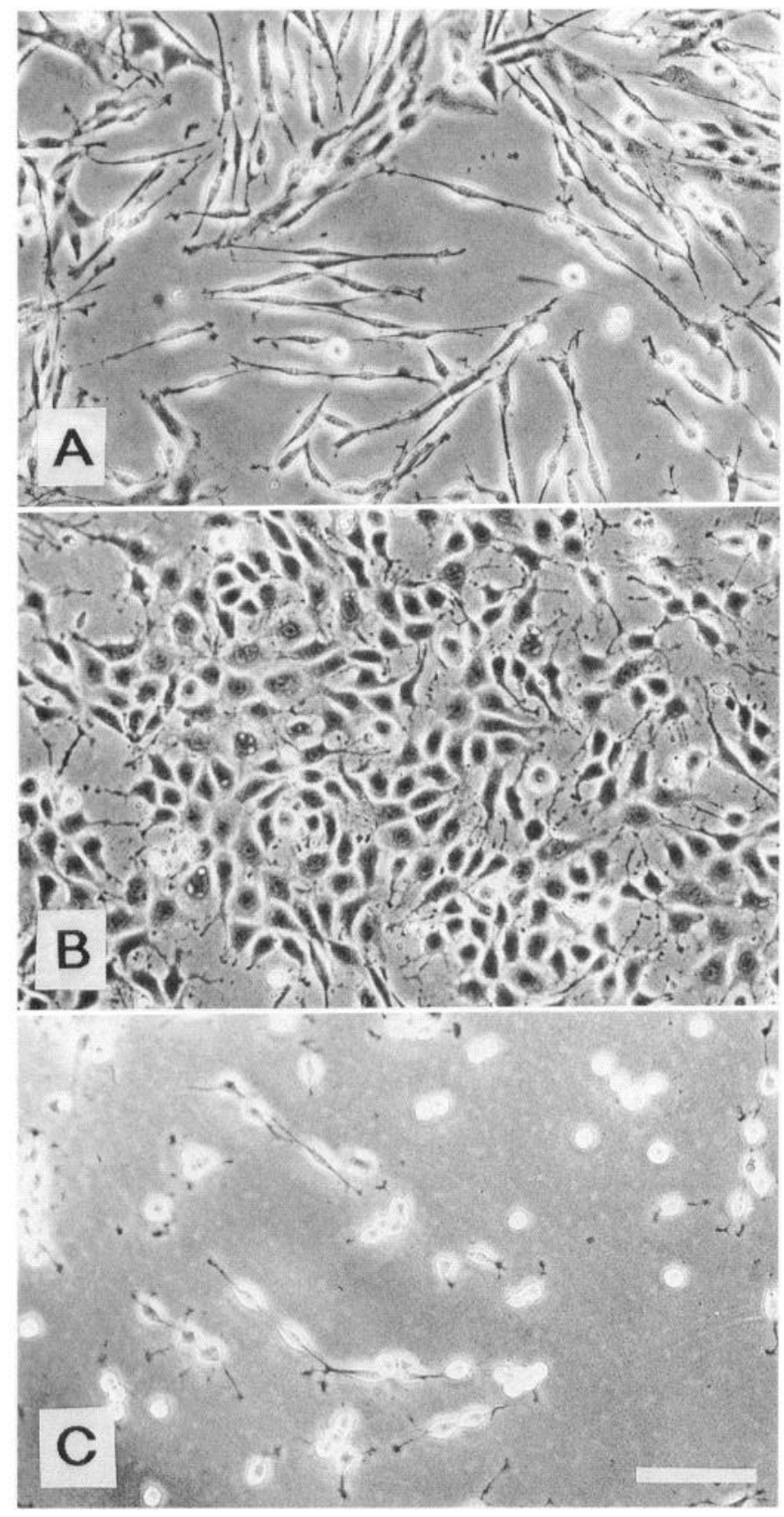

Figure 4. Immobilized B2C11 induces morphological changes in S-16 cells. Cells were exposed for $24 \mathrm{hr}$ to either tissue culture plastic in the presence of serum containing medium $(A)$, or $5 \mu \mathrm{g} / \mathrm{ml}$ immobilized B2C11 $(B)$ or 192-IgG $(C)$, in serum-free medium. Scale bar, $100 \mu \mathrm{m}$.

bilized B2C11 and 192-IgG can be distinguished by their morphology; on $\mathrm{B} 2 \mathrm{C} 11$ the cells flatten and spread within the first $30-45$ min of contact. As a result, these normally bipolar cells (Fig. 4a) resemble flat, polygonal fibroblasts after $24 \mathrm{hr}$ on B2C11 (Fig. 4b). Adhesion of S-16 cells to 192-IgG does not induce an obvious morphological transformation; the cells remain rounded or bipolar (Fig. $4 c$ ).

To determine whether there were any other differences in the adhesion of S-16 cells to immobilized B2C11 and 192-IgG, the rate and strength of cell adhesion to Ab-coated dishes was measured. The rate of adhesion was measured by incubating cells
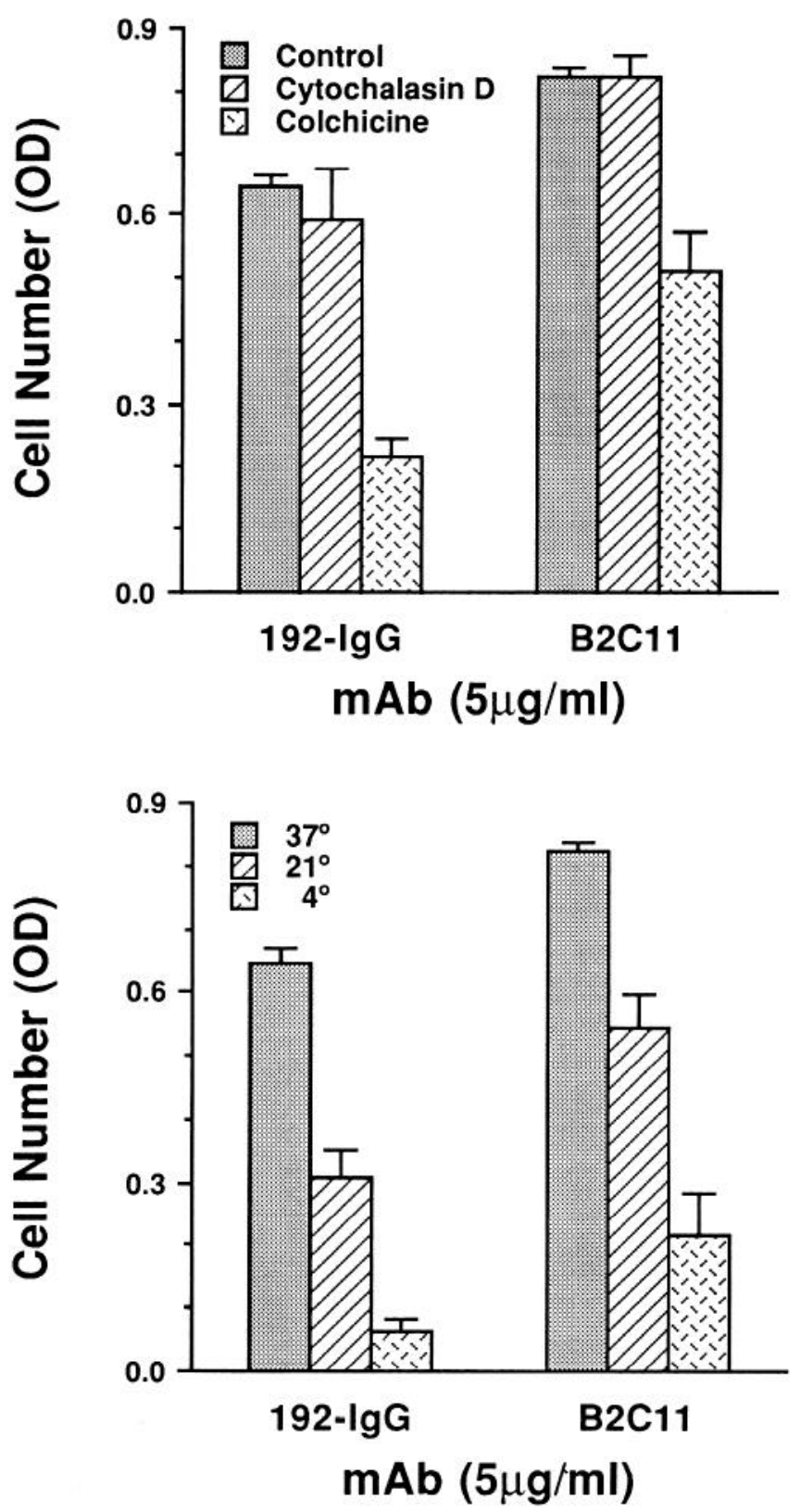

Figure 5. Effects of cytoskeleton-disrupting agents and temperature of S-16 adhesion on immobilized 192-IgG and B2C11;1.2 $\times 10^{4}$ cells were plated on each $\mathrm{mAb}$ and allowed to adhere for $90 \mathrm{~min}$ in the presence of each agent at $37^{\circ} \mathrm{C}$, or at the noted temperature before removal of unbound cells by centrifugation. The number of bound cells was determined spectrophotometrically by the MTS/PMS assay as described in Materials and Methods. Colchicine $(10 \mu \mathrm{M})$ but not Cytochalasin D $(20 \mu \mathrm{M})$ disrupts S-16 adhesion on both immobilized mAbs at $37^{\circ} \mathrm{C}$. Decreasing the temperature also disrupts S-16 adhesion on both immobilized mAbs.

on the mAbs for various times (15, 30, 45, 60, and $90 \mathrm{~min})$ followed by removal of nonadherent cells by centrifugation at $500 \mathrm{rpm}$ (the speed used in the standard adhesion assay). The strength of adhesion was measured by incubating cells for 90 min followed by centrifugation at higher speeds (1000 and 1500 $\mathrm{rpm}$ ). Results from these experiments indicate that initial binding of S-16 cells to $\mathrm{B} 2 \mathrm{C} 11$ occurs more rapidly and is followed by a tighter adhesion in comparison to $192-\mathrm{IgG}$ (data not shown). Another comparison involves measuring the affinity of 192-IgG 

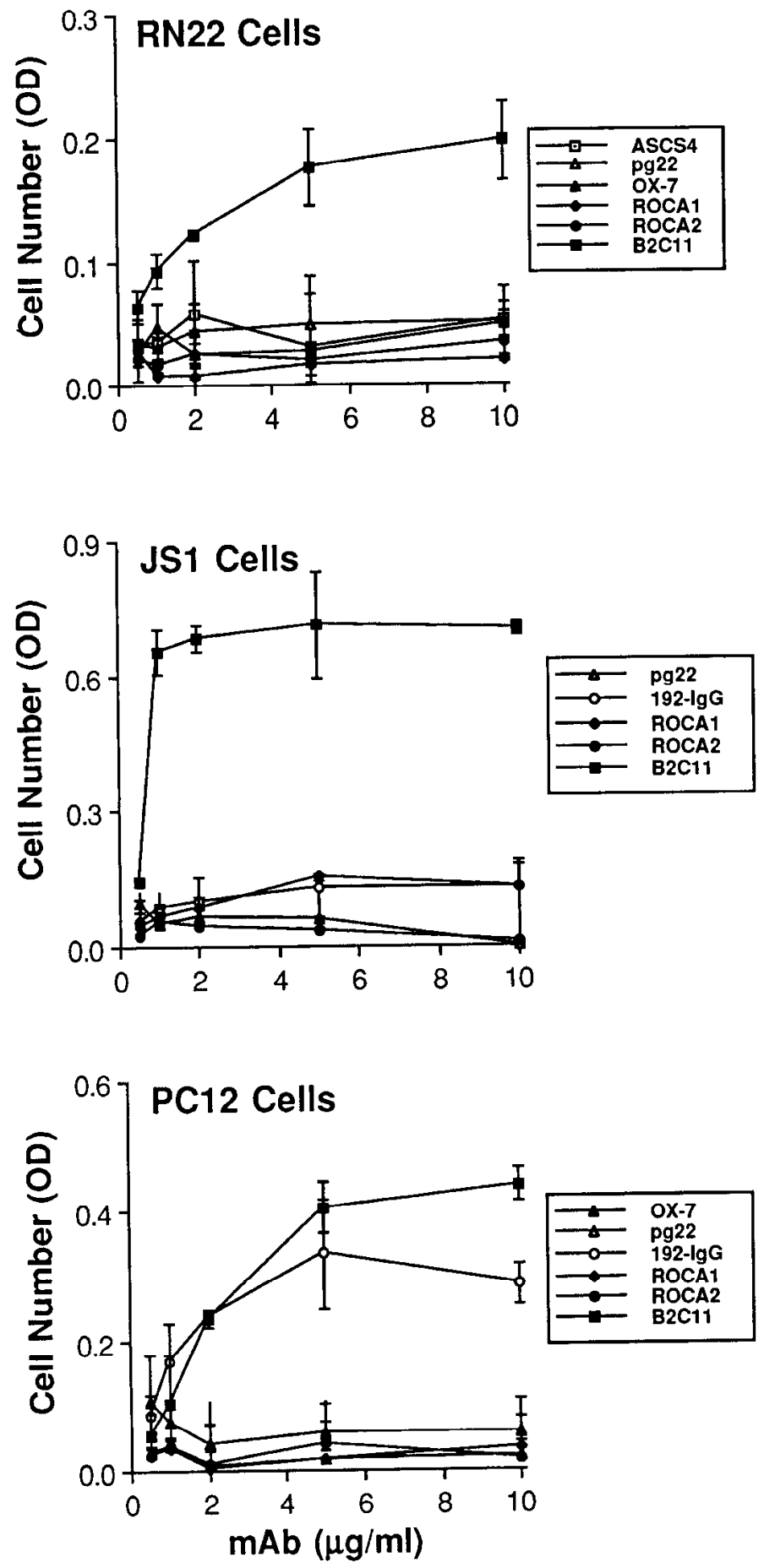

Figure 6. Adhesion of RN22, JS1, and PC12 cells to immobilized mAbs; $1 \times 10^{4} \mathrm{RN} 22$ and JS1 cells and $5 \times 10^{3} \mathrm{PCl} 2$ cells were added to wells containing various concentrations of immobilized mAbs. Cells were then incubated in serum-free medium for $90 \mathrm{~min}$, and unbound cells removed by centrifugation. The number of adherent cells was determined spectrophotometrically by the MTS/PMS assay. Not shown in the graphs are the O.D. numbers of cells adhering to 5\% BSA (used as a negative control): $0.036 \pm 0.009$ for RN22, $0.065 \pm 0.013$ for JS1, and $0.012 \pm 0.038$ for PC12 cells.

for $\mathrm{p} 75$, and ROCA2 and $\mathrm{B} 2 \mathrm{C} 11$ for CD9 using an ELISA with living S-16 cells. In this assay, 192-IgG and B2C11 have a similar affinity for the cells, which is twofold higher than that of ROCA2 for the same cells (data not shown).

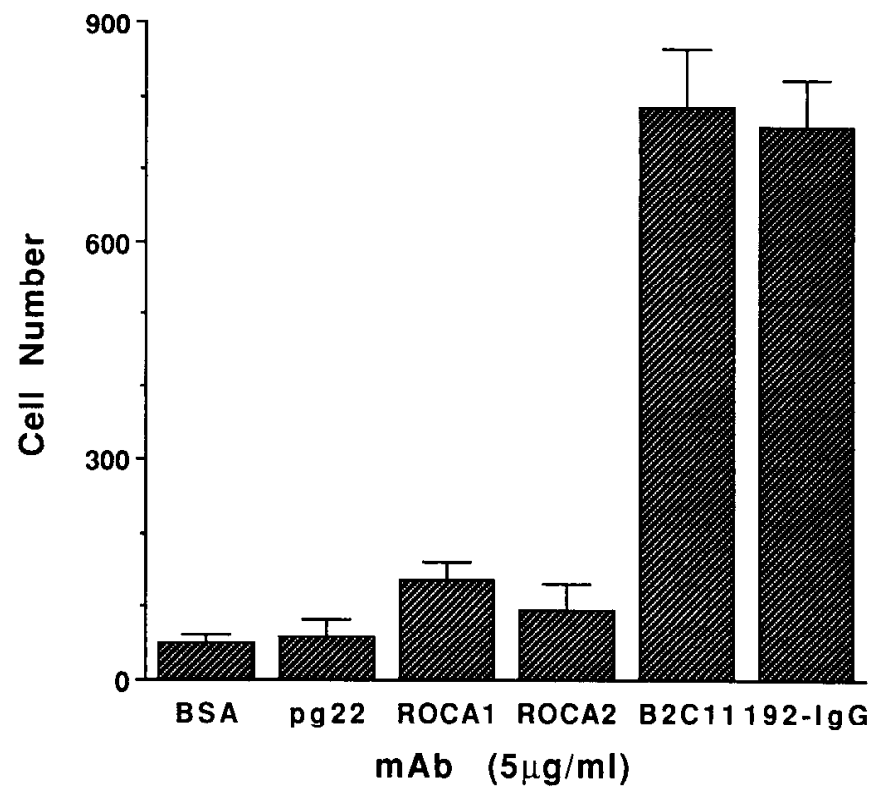

Figure 7. Adhesion of primary Schwann cells to immobilized mAbs; $2 \times 10^{4}$ cells were added to each well of a 96 well plate containing 5 $\mu \mathrm{g} / \mathrm{ml}$ of each $\mathrm{mAb}$ that was immobilized on a nitrocellulose substratum. Cells were then exposed to the immobilized mAbs in serum-free medium for 90 min prior to removal of unbound cells by centrifugation. Adherent cells were counted visually.

The B2C11-induced morphological changes and strong adhesion of S-16 cells suggest that the cytoskeleton and active cellular energy might be involved. In order to examine this possibility, adhesion assays were carried out at $37^{\circ} \mathrm{C}$, in the presence of the microfilament inhibitor, cytochalasin $\mathrm{D}(20 \mu \mathrm{M})$, or the microtubule inhibitor, colchicine $(10 \mu \mathrm{M})$. As shown by the data in Figure 5, cytochalasin D has no effect on cell adhesion. In contrast, colchicine inhibits adhesion to the $\mathrm{B} 2 \mathrm{Cl} 1$ and $192-\mathrm{IgG}$ surfaces by approximately $32 \%$ and $76 \%$, respectively. Similarly, adhesion of S-16 cells to immobilized B2C11 and $192-\mathrm{IgG} \mathrm{mAbs}$ is influenced by temperature. S-16 adhesion to both $\mathrm{mAbs}$ dramatically decreases as the temperature is lowered from $37^{\circ} \mathrm{C}$ to $4^{\circ} \mathrm{C}$ (Fig. 5).

\section{Immobilized antibodies promote adhesion of RN22, JS-1, PC12, and primary Schwann cells}

To test the generality of the effects observed with S-16 cells, we tested other glial cell lines derived from peripheral nerve (RN22, JS-1), the sympathetic neuron-like line, PC12, as well as dissociated, primary Schwann cells. In addition to B2C11 and 192$\mathrm{IgG}$, two other mAbs that also recognize cell surface antigens were used as controls: pg22 (anti-heparan sulfate proteoglycan) and OX-7 (anti-Thy-1). The results of adhesion assays using the rat Schwannoma cell lines, RN22, JS-1, and the adrenal pheochromocytoma, $\mathrm{PCl}$, are illustrated in Figure 6. B2C11 consistently promotes cell adhesion at mAb concentrations of $0.5-$ $10 \mu \mathrm{g} / \mathrm{ml}$. ROCA2, pg22, and OX-7, mAbs that strongly label these cells (data not shown), do not have any cffect on adhesion. As expected, ROCA1 and ASCS4, mAbs that do not label these cells, also have no effect. 192-IgG, however, strongly promotes PC1 2 cell adhesion (Fig. 6). No morphological changes were observed in the RN22, JS-1, and PC1 2 cells that adhered to the B2C11 surface.

The ability of these various mAbs to promote cell adhesion 


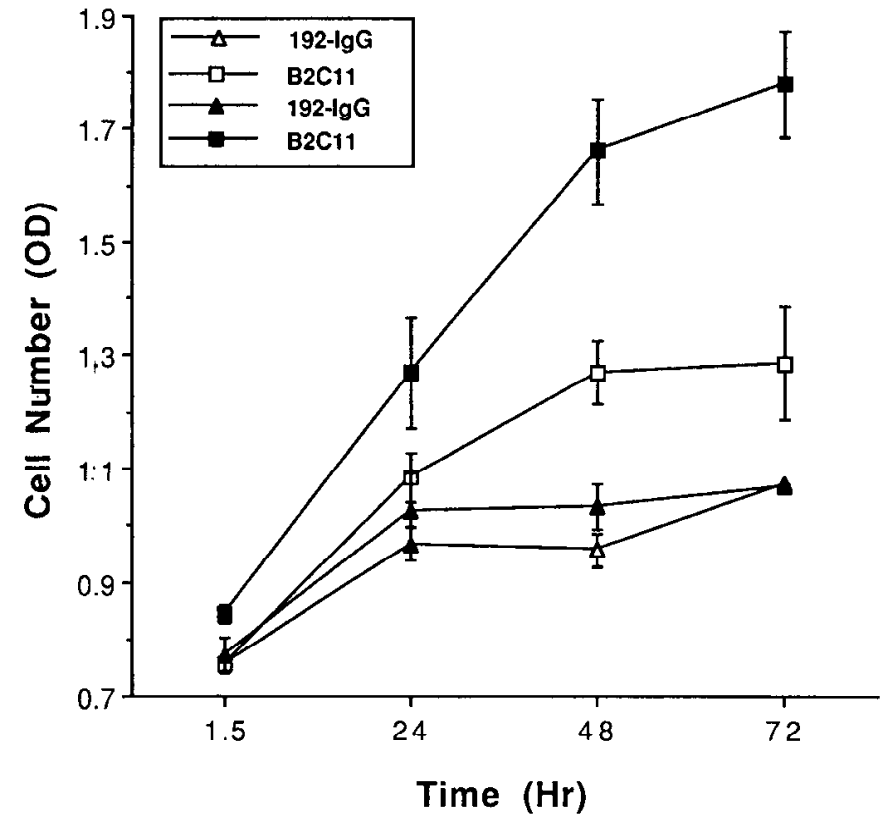

Figure 8. Proliferation of S-16 cells on immobilized B2C11; 2 (open symbols) and $5 \mu \mathrm{g} / \mathrm{ml}$ (solid symbols) of each $\mathrm{mAb}$ was immobilized on a nitrocellulose substratum. Cells $\left(1 \times 10^{4} /\right.$ well $)$ were then exposed to the immobilized mAbs in serum-free medium for $90 \mathrm{~min}$ followed by removal of unbound cells. The number of cells was determined spectrophotometrically by the MTS/PMS assay at 1.5, 24, 48, and $72 \mathrm{hr}$.

was also tested with primary Schwann cells dissociated from neonatal rat sciatic nerve. Schwann cells were identified on the basis of their expression of both CD9 and p75 ${ }^{\text {LNGFR }}$, as well as by their characteristic bipolar morphology (data not shown). Results from a $90 \mathrm{~min}$ adhesion assay using $5 \mu \mathrm{g} / \mathrm{ml}$ of each $\mathrm{mAb}$ are illustrated in Figure 7. A clear enhancement of cell adhesion is seen with B2C11 and 192-IgG. Some flattening of cells on the B2Cl1 surface was also observed (data not shown).

\section{Immobilized B2C11 stimulates proliferation of S-16 Schwann} cells

Another function relevant for the potential signaling role for CD9 and other members of the "tetraspan" family, is growth regulation. Since immobilized $\mathrm{B} 2 \mathrm{C} 11$ and $192-\mathrm{IgG}$ promote S-16 cell adhesion, it was possible to compare the ability of these two $\mathrm{mAbs}$ to influence cell proliferation. The assay was carried out in serum-free medium lacking any exogenous growth factors or other proteins. Both mAbs were tested at 2 and at 5 $\mu \mathrm{g} / \mathrm{ml}$. Although similar numbers of cells adhere after $90 \mathrm{~min}$ to both mAbs, only $\mathrm{B} 2 \mathrm{C} 11$ strongly induces $\mathrm{S}-16$ cells to proliferate for the subsequent $72 \mathrm{hr}$ (Fig. 8). Very slight or no growth of S- 16 cells results when these cells are plated in serum-free medium on tissue culture plastic in the absence of $\mathrm{mAb}$ and monitored for $3 \mathrm{~d}$ (data not shown).

The striking nature of this proliferative effect is illustrated in the photomicrographs in Figure 9. In spots of immobilized B2C11 and 192-IgG, defined fields of cells were monitored at 2, 24, and $72 \mathrm{hr}$. At $2 \mathrm{hr}$, a few more cells adhere to B2C11 than 192IgG. By $24 \mathrm{hr}$, many more flattened cells are present on B2C11. A very clear difference between the cells on these two mAbs appears at $72 \mathrm{hr}$; a monolayer of flat, polygonal S-16 cells was generated on $\mathrm{B} 2 \mathrm{C} 11$, in contrast to the few rounded or bipolar cells present on 192-IgG.

\section{Discussion}

\section{$C D 9$ involvement in cell adhesion}

In order to begin to examine the potential functions of CD9 in the nervous system, we have carried out antibody perturbation experiments with cultured cclls. Adhesion and proliferation assays were conducted with a number of Schwann cell lines (S16, RN22, and JS1), primary Schwann cells, as well as PC12 cells. The data reveal that $\mathrm{B} 2 \mathrm{C} 11$, one of the mAbs against $\mathrm{CD}$, promotes adhesion of all cells tested. Surprisingly, the $\mathrm{p} 75^{\mathrm{LNGFR}}$ $\mathrm{mAb}, 192-\mathrm{IgG}$, also promotes cell adhesion. Both of these adhesive effects where demonstrated only when the mAbs were immobilized on a nitrocellulose substratum. A possible explanation for the immobilization requirement is that this method allows binding to CD9 or $\mathrm{p} 75$ at the cell surface without internalization, thus prolonging the ability of the $\mathrm{mAb}$ to maintain a sustained activation signal. This hypothesis was also proposed to explain the proliferation of human $\mathrm{T} 4$ cells in response to immobilized anti-CD3 mAb (Geppert and Lipsky, 1987). That study also reported that the mAb that stimulates cell proliferation had no effect when presented to cells in soluble form, as was the case in our experiments.

In contrast to the effects displayed by $\mathrm{B} 2 \mathrm{C} 11$, the other antiCD9 mAb, ROCA2, which shows the same affinity to $S-16$ cells as B2C11 (at $5 \mu \mathrm{g} / \mathrm{ml}$ ), showed no effect on adhesion. This result serves as an important control experiment since it suggests that this adhesion assay is not merely measuring Ab-cell binding, but rather a possible sequence of downstream events necessary for adhesion. Simple Ab-cell binding was not sufficient for cell attachment to the nitrocellulose surface after centrifugation at $500 \mathrm{rpm}$. Since it is known that the two mAbs (ROCA2 and B2C11) recognize distinct epitopes on CD9 (Kaprielian et al., 1994), the effect of $\mathrm{B} 2 \mathrm{C} 11$ on cell adhesion and proliferation may depend on stimulation through a particular site on the protein. We speculate that the site recognized by $\mathrm{B} 2 \mathrm{C} 11$ is a functional epitope and may be a binding site for a natural ligand of $\mathrm{CD} 9$. In this view, B2C11 would mimic the effects of the natural ligand. In contrast, ROCA2 recognizes a nonfunctional epitope and therefore displays no effect. It is possible that the slight difference between ROCA2 and $\mathrm{B} 2 \mathrm{C} 11$ in their affinities for $\mathrm{CD} 9$ may be responsible for their different activating properties. Differences in affinity, however, will not explain why B2C11 stimulates S-16 cell proliferation while 192-IgG does not. Lastly, the third anti-CD9 mAb, ROCA1, does not immunolabcl living cclls and does not show any biological effects. We postulate that the ROCAI epitope is blocked on the surface of cells tested here as it appears to be in Schwann cells in caudal segments of intercostal nerve, satellite cells of caudal sympathetic ganglia and in sciatic nerve (Suzue et al., 1990; Kaprielian and Patterson, 1993). This masking would apply only to intact cells, however; ROCAl binds to CD9 on immunoblots of all of these cells.

The induction of adhesion by mAb 192-IgG in S-16, PC12 and primary Schwann cells was a surprising finding, since it was not known that the low affinity NGF receptor, p75, could play a role in cell adhesion. It is hypothesized that p75 functions as part of a multimeric complex with the high affinity tyrosinekinase receptors (trk oncogenes) to mediate the actions of the various neurotrophins (reviewed in Barker and Murphy, 1992). Although this may be the primary function of $p 75$, our data suggest that it could also play an indirect rolc in cell adhesion.

The adhesion of S-16 cells promoted by B2C11 and by 192 - 


\section{B2C11}

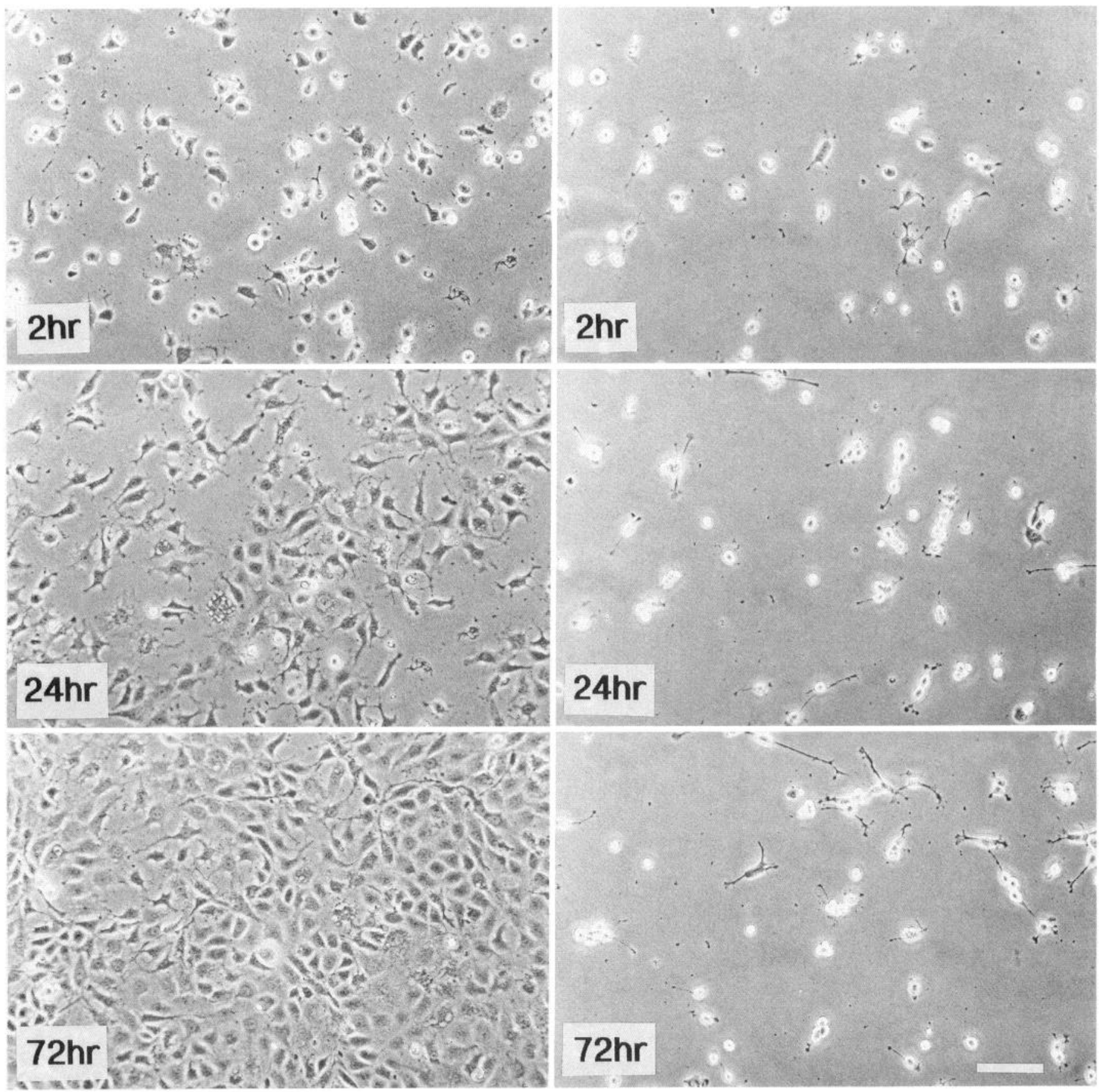

Figure 9. Proliferation of S-16 cells on immobilized B2C11. One microliter of each $\mathrm{mAb}(250 \mathrm{ng})$ was dotted in the center of a $33 \mathrm{~mm}$ petri dish on a nitrocellulose substratum. Cells were then exposed to the immobilized mAbs for 90 min in serum-free medium prior to removal of unbound cells. The same fields of cells were then photographed at 2,24 , and $72 \mathrm{hr}$. Scale bar, $100 \mu \mathrm{m}$.

IgG is similar in that cells on both mAbs respond in the same way to the various treatments applied here (temperature, cytochalasin D, and colchicine). Binding to B2C11 and 192-IgG can, however, be distinguished by the morphology of the S-16 cells and the rate and strength of adhesion. Contact of S-16 cells with B2C11 (unlike 192-IgG) leads to a rapid and tight adhesion, followed by striking morphological changes. Consequently, these normally bipolar cells resemble flat, polygonal fibroblasts, prob- ably as a result of cytoskeletal protein rearrangements. This notion is supported by previous studies with immobilized mAbs. For example, an immobilized $\mathrm{mAb}$ directed against the leukocyte function-associated antigen 1 (LFA-1) causes a human $\mathrm{T}$ cell line to develop dendritic processes containing microtubules and intermediate filaments (Kelleher et al., 1990). An immobilized $\mathrm{mAb}$ against a novel $20 \mathrm{kDa}$ protein induces both cell adhesion and cytoskeleton-dependent morphological changes 
in a number of $\mathrm{T}$ cell lines (Lin et al., 1992). These changes include the formation of processes similar to those seen with the anti-LFA-1 mAb.

\section{CD9 involvement in cell growth regulation}

Although both 192-IgG and B2C11 promote cell adhesion, only B2C 11 strongly induces proliferation of S-16 cells in serum-free medium, indicating that adhesion does not necessarily lead to proliferation. Thus, adhesion and proliferation are separable and can be studied independently in this paradigm. It is notcworthy that the serum-free medium used in these assays was not supplemented with any growth factors or other proteins. We speculate that the capability of S-16 cells to survive and grow under these conditions is due to CD9-stimulated production and release of an autocrine growth factor(s). This hypothesis is supported by the demonstration that both normal and immortalized Schwann cells can secrete an autocrine growth factor that is effective in stimulating their proliferation (Porter et al., 1987). In addition, it is well established that normal and immortalized Schwann cells produce platelet-derived growth factor B-chain, brain-derived neurotrophic factor, Schwannoma-derived growth factor, ciliary neurotrophic factor, NGF (reviewed in Eccleston, 1992; LoPachin and Aschner, 1993; Reynolds and Woolf, 1993).

Support for our finding that CD9 is involved in proliferation of Schwann cells comes from previous perturbation experiments implicating other members of the tetraspan family (Gil et al., 1992 ) in cell growth regulation. For example, mAbs against CD37, a human B-lymphocyte-associated antigen, enhance the mitogenic effect of anti-immunoglobulin antibodies on B cells but inhibit activation induced by anti-CD20 mAbs and B-cell growth factor on the same cells (Ledbetter et al., 1987). Moreover, a mAb against TAPA-1, a lymphoid cell surface antigen, induces antiproliferative effects on numerous human lymphoid cell lines (Oren et al., 1990). More recently, a mAb against OX44 (the rat homologue of human CD53) was found to be mitogenic for primary rat splenic T cells (Bell et al., 1992). Lastly, ME491, a melanoma-associated antigen that is expressed strongly during the early stages of tumor progression, has been suggested to serve as a rapid growth inhibitory protein (Hotta et al., 1988).

In addition to the data on Schwann cell adhesion and proliferation presented in this article, Anton et al. (1994) provide evidence for CD9 involvement in Schwann cell migration. Taken together, these results suggest that CD9 is a multifunctional molecule, implicated in a variety of Schwann cell functions in vitro. We hypothesize that $\mathrm{B} 2 \mathrm{Cl} 1$ mimics a natural ligand of CD9, and upon binding, exerts its effects by inducing activation signals, likely candidates being increased $\mathrm{Ca}^{2+}$ concentration and protein phosphorylation (Anton et al., 1994). Since CD9 protein and mRNA are expressed by peripheral neurons and glia in situ (Tole and Patterson, 1993; Kaprielian et al., 1994), it is possible that CD9 is a regulator of migration, adhesion, and/or growth control in vivo.

\section{References}

Akeson R, Warren SL (1984) Detection of a cell surface antigen found on rat peripheral nervous system neurons and multiple glia: astrocytes, oligodendrocytes, and Schwann cells. J Neurosci Res 12:4157.

Anton ES, Hadjiargyrou M, Patterson PH, Matthew WD (1995) CD9 plays a role in Schwann cell migration in vitro. J Neurosci 15:584 595.

Azzarone B, Krief P, Soria J, Bouchiex C (1985) Modulation of fi- broblast-induced clot retraction by calcium channel blocking drugs and the monoclonal antibody ALB 6 . J Cell Physiol 125:420-426.

Barker PA, Murphy RA (1992) The nerve growth factor receptor: a multicomponent system that mediates the actions of the neurotrophin family of proteins. Mol Cell Biochem 110:1-15.

Barltrop JA, Owen TC, Cory AH, Cory JG (1991) 5-(3-Carboxymethoxyphenyl)-2-(4,5-dimethylthiazolyl)-3-(4-sulfophenyl) tetrazolium, inner salt (MTS) and related analogs of 3-(4,5-dimethylthiazolyl)-2,5-diphenyltetrazolium bromide (MTT) reducing to purple water-soluble formazans as cell-viability indicators. Bioorg Med Chem Lett 1:611-614.

Bell GM, Seaman WE, Niemi EC, Imboden JB (1992) The OX-44 molecule couples to signaling pathways and is associated with CD2 on rat $\mathrm{T}$ lymphocytes and a natural killer cell line. J Exp Med 175: 527-536.

Boucheix C, Benoit P (1988) CD9 antigen: will platelet physiology help to explain the function of a surface molecule during hematopoietic differentiation? Nouv Rev Fr Hematol 30:201-202.

Boucheix C, Soria C, Mirshahi M, Soria J, Perrot J-Y, Fournier N, Billard M, Rosenfeld N (1983) Characteristics of platelet aggregation induced by the monoclonal antibody $\mathrm{ALB}_{6}$ (acute lymphoblastic leukemia antigen $p$ 24). Inhibition of aggregation by $\mathrm{ALB}_{6}$ Fab. FEBS Lett 161:289-295.

Boucheix C, Benoit P, Krief P, Billard M, Mishal Z, Azzarone B, Rendu E, Esnouf J, Bredoux R, Levy-Toledano S, Soria C, Perrot JY, Mirshahi M, Giannoni F, Bernadou A, Soria J (1987) Platelet aggregation induced by $\mathrm{CD} 9 \mathrm{mAbs}$. Mechanisms and comparisons with platelet aggregating properties of mAbs directed against other membrane antigens. In: Platelet aggregation induced by CD $9 \mathrm{mAbs}$. Mechanisms and comparisons with platelet aggregating properties of $\mathrm{mAbs}$ directed against other membrane antigens (McMichael AJ, ed), pp 780-782. Oxford: Oxford UP.

Boucheix C, Benoit P, Frachet P, Billard M, Worthington RE, Gagnon J, Uzan G (1991) Molecular cloning of the CD9 antigen. J Biol Chem 266:117-122.

Brown JG, Almond BD, Naglich JG, Eidels L (1993) Hypersensitivity to diphtheria toxin by mouse cells expressing both diphtheria toxin receptor and CD9 antigen. Proc Natl Acad Sci USA 90:8184-8188.

Chandler CE, Parsons LM, Hosang M, Shooter EM (1984) A monoclonal antibody modulates the interaction of nerve growth factor with PC1 2 cells. J Biol Chem 259:6882-6889.

Eccleston PA (1992) Regulation of Schwann cell proliferation: mechanisms involved in peripheral nerve development. Exp Cell Res 199: $1-9$

Forsyth KD (1991) Anti-CD9 antibodies augment neutrophil adherence to endothelium. Immunology 72:292-296.

Geppert TD, Lipsky PE (1987) Accessory cell independent proliferation of human T4 cells stimulated by immobilized monoclonal antibodies to CD3. J Immunol 138:1660-1666.

Gil ML, Vita N, Lebel-Binay S, Miloux B, Chalon P, Kaghad M, Marchiol-Fournigault M, Conjeaud H, Caput D, Ferrara P, Fradelizi D, Quillet-Mary A (1992) A member of the tetraspans transmembrane protein superfamily is recognized by a monoclonal antibody raised against an HLA class I-deficient, lymphokine-activated killer-susceptible, B lymphocyte line. Cloning and preliminary functional studies. J Immunol 148:2826-2833.

Goda S, Hammer J, Kobiler D, Quarles RH (1991) Expression of the myelin-associated glycoprotein in cultures of immortalized Schwann cells. J Neurochem 56:1354-1361.

Greene LA, Tischler AS (1976) Establishment of a noradrenergic clonal line of rat adrenal pheochromocytoma cells which respond to nerve growth factor. Proc Natl Acad Sci USA 73:2424-2428.

Griffith L, Slupsky J, Seehafer J, Boshkov L, Shaw ARE (1991) Platelet activation by immobilized monoclonal antibody: evidence for a CD9 proximal signal. Blood 78:1753-1759.

Hawrot E, Patterson PH (1979) Long-term culture of dissociated sympathetic neurons. In: Long-term culture of dissociated sympathetic neurons (Jakoby WB, Pastan IH, eds), pp 574-583. San Diego: Academic.

Higashara M, Takahata K, Yatomi Y, Nakahara K, Kurokawa K (1990) Purification and partial characterization of CD9 antigen of human platelets. FEBS Lett 264:270-274

Higashihara M, Maeda H, Shibata Y, Kume S, Ohashi T (1985) A monoclonal anti-human platelet antibody: a new platelet aggregating substance. Blood 65:382-391. 
Hotta H, Ross AH, Huebner K, Isobe M, Wendenborn S, Chao MV, Ricciardi RP, Tsujimoto Y, Croce CM, Koprowski H (1988) Molecular cloning and characterization of an antigen associated with early stages of melanoma tumor progression. Cancer Res 48:2955-2962.

Ikeyama S, Koyama M, Yamaoko M, Sasada R, Miyake M (1993) Suppression of cell motility and metastasis by transfection with human motility-related protein (MRP-1/CD9) DNA. J Exp Med 177: 1231-1237.

Jennings LK, Fox CF, Kouns WC, McKay CP, Ballou LR, Schultz HE (1990) The activation of human platelets mediated by anti-human platelet p24/CD9 monoclonal antibodies. J Biol Chem 265:38153822.

Jones NH, Borowitz MJ, Metzgar RS (1982) Characterization and distribution of a 24,000 -molecular weight antigen define by a monoclonal antibody (DU-ALL-I) elicited to common acute lymphoblastic leukemia (cALL) cells. Leuk Res 6:449-460.

Kaprielian Z, Patterson PH (1993) Surface and cytoskeletal markers of rostrocaudal position in the mammalian nervous system. J Neurosci 13:2495-2508.

Kaprielian Z, Cho K-O, Hadjiargyrou M, Patterson PH (1995) CD9, a major platelet cell surface glycoprotein, is a ROCA antigen and is expressed in the nervous system. J Neurosci 15:562-573.

Kelleher D, Murphy A, Derek C (1990) Leukocyte function-associated antigen 1 (LFA-1) is a signaling molecule for cytoskeletal changes in a human T cell line. Eur J Immunol 20:2351-2354.

Kemshead JT, Fritschy J, Asser U, Sutherland R, Greaves MF (1982) Monoclonal antibodies defining markers with apparent selectivity for particular haematopoietic cell types may also detect antigens on cells of neural crest origin. Hybridoma 1:109-123.

Kersey JS, Lebien T, Abramson CS, Sutherland R, Greaves MF (1981) p24: a human leukemia associated and lymphohematopoietic progenitor cell surface structure identified with monoclonal antibody. J Exp Med 153:726-731.

Kimura H, Fischer WH, Schubert D (1990) Structure, expression and function of a schwannoma-derived growth factor. Nature 348:257260.

Komada Y, Peiper SC, Melvin SL, Metzgar WD, Tarnowski BH, Green AA (1983) A monoclonal antibody (SJ-9A4) to p24 present on alls, neuroblastomas and platelets. I. Characterization and development of a unique radioimmunometric assay. Leuk Res 7:487-498.

Lagenaur C, Lemmon V (1987) An L1-like molecule, the 8D9 antigen is a potent substrate for neurite extension. Proc Natl Acad Sci USA 84:7753-7757.

Lanza F, Wolf D, Fox CF, Kieffer N, Seyer JM, Fried VA, Coughlin SR, Phillips DR, Jennings LK (1991) cDNA cloning and expression of platelet p24/CD9. J Biol Chem 266:10638-10645.

Ledbetter JA, Shu G, Clark EA (1987) Monoclonal antibodies to a new gp40-45 (CD37) B-cell-associated cluster group modulate B-cell proliferation. In: Monoclonal antibodies to a new gp40-45 (CD37) B-cell-associated cluster group modulate B-cell proliferation (McMichael AJ, ed), pp 339-340. Oxford: Oxford UP.

Lin SL, Derr D, Hildreth JEK (1992) A monoclonal antibody against a novel 20-kDa protein induces cell adhesion and cytoskeleton-dependent morphologic changes. J Immunol 149:2549-2559.

LoPachin RM, Aschner M (1993) Contemporary issues in toxicology. Glial-neuronal interactions: relevance to neurotoxic mechanisms. Toxicol Appl Pharmacol 118:141-158.

Lotz MM, Burdsal CA, Erickson HP, McClay DR (1989) Cell adhesion to fibronectin and tenascin: quantitative measurements of initial binding and subsequent strengthening response. J Cell Biol 109:17951805 .

Martin-Alonso J-M, Hernando N, Ghosh S, Coca-Prados M (1992)
Molecular cloning of the bovine CD9 antigen from ocular ciliary epithelial cells. J Biochem 112:63-67.

Mason DW, Williams AF (1980) The kinetics of antibody binding to membrane antigens in solution and at the cell surface. Biochem J 187:1-20.

Masselis-Smith A, Jensen GS, Seehater JG, Slupsky JR, Shaw ARE (1990) Anti-CD9 monoclonal antibodies induce homotypic adhesion of pre-B cell lines by a novel mechanism. J Immunol 144:1607-1613.

Matthew WD, Greenspan RJ, Lander AD, Reichardt LF (1985) Immunopurification and characterization of a neuronal heparan sulfate proteoglycan. J Neurosci 5:1842-1850.

Miller JL, Kupinski JM, Hustad KO (1986) Characterization of a platelet membrane protein of low molecular weight associated with platelet activation following binding by monoclonal antibody $\mathrm{AG}-1$. Blood 68:743-751.

Mitamura T, Iwamoto R, Umata T, Tomo Y, Urabe I, Tsuneoka M, Mekada E (1992) The 27-kD diphtheria toxin receptor-associated protein (DRAP27) from Vero cells is the monkey homologue of human CD9 antigen: expression of DRAP27 elevates the number of diphtheria toxin receptors on toxin-sensitive cells. J Cell Biol 118: 1389-1399.

Miyake, M, Koyama M, Seno M, Ikeyama S (1991) Identification of the motility-related protein (MRP-1), recognized by monoclonal antibody M31-15, which inhibits cell motility. J Exp Med 174:13471354.

Oren R, Takahashi S, Doss C, Levy R, Levy S (1990) TAPA-1, the target of an antiproliferative antibody, defines a new family of transmembrane proteins. Mol Cell Biol 10:4007-4015.

Pfeiffer SE, Betschart B, Cook J, Mancini PE, Morris RJ (1978) Glial cell lines. In: Glial cell lines (Federoff S, Hertz L, eds), pp 287-346. New York: Academic.

Porter S, Glaser L, Bunge RP (1987) Release of autocrine growth factor by primary and immortalized Schwann cells. Proc Natl Acad Sci USA 84:7768-7772.

Reynolds ML, Woolf CJ (1993) Reciprocal Schwann cell-axon interactions. Curr Opin Neurobiol 3:683-693.

Rubinstein E, Billard M, Plaisance S, Prenant M, Boucheix C (1993) Molecular cloning of the mouse equivalent of CD9 antigen. Thromb Res 71:377-383.

Slupsky JR, Seehafer JG, Tang S-C, Masselis-Smith A, Shaw ARE (1989) Evidence that monoclonal antibodies against CD9 antigen induce specific association between CD9 and the platelet glycoprotein IIb-IIIa complex. J Biol Chem 264:12289-12293.

Suzue T, Kaprielian Z, Patterson PH (1990) A monoclonal antibody that defines rostrocaudal gradients in the mammalian nervous system. Neuron 5:421-431.

Sweadner KJ (1983) Post-translational modification and evoked release of two large surface proteins of sympathetic neurons. J Neurosci 3:2504-2517.

Tole S, Patterson PH (1993) Distribution of CD9 in the developing and mature rat nervous system. Dev Dynamics 197:94-106.

Von dem Borne AEGK, Modderman PW, Admiraal LG, Nieuwenhuis HK (1989) Platelet antibodies, the overall results. In: Platelet antibodies, the overall results (Knapp W, Dorken B, Gilks WR, Rieber EP, Schmidt RE, Stein H, Von dem Borne AEGK, eds), pp 951-960. Oxford: Oxford UP.

Yatomi Y, Ozaki Y, Satoh K, Kume S (1993) Anti-CD9 monoclonal antibody elicits staurosporine inhibitable phosphatidylinositol 4,5biphosphate hydrolysis, phosphatidylinositol 3,4-biphosphate synthesis, and protein-tyrosine phosphorylation in human platelets. FEBS Lett 322:285-290. 